\title{
ZNACZENIE KORPORACJI TRANSNARODOWYCH W GOSPODARCE ŚWIATOWEJ
}

\section{WSTĘP}

Współcześnie uważa się, że korporacje transnarodowe, obok państw, instytucji i organizacji międzynarodowych, stały się głównym i niezwykle aktywnym podmiotem procesów globalizacji o istotnej sile wpływu na zmiany zachodzące w gospodarce światowej, jak również inspiratorami nowego typu relacji z państwami. Tymczasem sposób funkcjonowania firm o globalnym zasięgu działania budzi wiele kontrowersji. $Z$ jednej strony przysparzają krajowi goszczącemu szereg określonych korzyści (nowe inwestycje, miejsca pracy), z drugiej negatywnie ocenia się drenowanie przez korporacje gospodarek lokalnych, ich próby działania ponad ustawodawstwem krajowym czy transfer zysków zagranicę. Celem artykułu jest identyfikacja obszarów ekonomicznego oddziaływania tych podmiotów we współczesnej gospodarce. W artykule podjęto próbę weryfikacji tezy, iż w warunkach gospodarki globalnej korporacje transnarodowe (KTN) odgrywają coraz większą rolę w kształtowaniu międzynarodowych stosunków ekonomicznych. Będące $\mathrm{w}$ ich posiadaniu zasoby rzeczowe i finansowe umożliwiają korporacjom wywieranie realnego wpływu na innych uczestników stosunków międzynarodowych. W artykule wykorzystano analizę literatury przedmiotu oraz analizę danych statystycznych.

\section{ISTOTA KORPORACJI TRANSNARODOWYCH}

W polskiej i zagranicznej literaturze przedmiotu spotkać można nie tylko różne definicje KTN ale także dość znaczną liczbę zamienników tego terminu. 
Jedne z nich eksponują aspekt własnościowy, inne podkreślają organizacyjno-strukturalny lub funkcjonalny wymiar działalności tych szczególnych przedsiębiorstw. Jako synonimy słowa korporacje występują takie określenia jak: przedsiębiorstwa, firmy, kompanie, spółki, koncerny, towarzystwa lub konglomeraty. $Z$ kolei obok przymiotnika transnarodowe funkcjonują terminy: wielonarodowe, globalne, międzynarodowe, ponadnarodowe oraz światowe. W publikacjach OECD oraz Banku Światowego używa się pojęcia przedsiębiorstwa wielonarodowe (multinational enterprises lub multinationals). Zróżnicowanie nazewnictwa oraz brak jednej powszechnie przyjętej definicji wynikają z trudności z precyzyjnym określeniem relacji tych podmiotów $\mathrm{z}$ innymi uczestnikami stosunków międzynarodowych, jak również kompleksowym sprecyzowaniem przejawów ich oddziaływania na międzynarodowe środowisko. Pomimo tej różnorodności w opinii Rady Ekonomiczno-Społecznej ONZ najbardziej trafnym pojęciem oddającym istotę tych podmiotów są właśnie korporacje transnarodowe ${ }^{1}$. Stąd w publikacjach UNCTAD (m.in. World Investment Report) $\mathrm{i}$ innych agend ONZ, także w literaturze polskiej, używa się pojęcia KTN w odniesieniu do jednostek (podmiotów gospodarczych), posiadających zagranicą aktywa umożliwiające im podjęcie tam procesów produkcji dóbr i usług oraz generujące przychód w co najmniej dwóch krajach². W szerszym ujęciu KTN to przedsiębiorstwo będące spółką akcyjną lub inną jednostką gospodarczą, składające się z przedsiębiorstwa macierzystego, posiadającego kontrolę nad co najmniej 10\% akcji lub innych udziałów w odniesieniu do jednostek gospodarczych zlokalizowanych poza jego krajem pochodzenia i afiliowanych przy nim przedsiębiorstw zagranicznych tj.: jednostek zależnych (subsidiares), w których 50\% akcji lub innych zasobów kontrolowanych jest przez przedsiębiorstwo macierzyste, jednostek stowarzyszonych (associated) - odpowiednio od $10 \%$ do $50 \%$ oraz filii i oddziałów (branches), pozostających w całości pod kontrolą firmy-matki(100\% udziałów) ${ }^{3}$. W opinii Centrum ONZ ds. Korporacji Transnarodowych (UNCTC) do innych ważnych cech charakteryzujących KTN należy stosowanie przez firmę macierzystą jednego systemu kontroli i zarządzania filiami (oddziałami), co umożliwia prowadzenie wspólnej polityki i strategii działania, realizowanej z reguły przez jeden ośrodek decyzyjny oraz występowanie silnych wzajemnych powiązań gospodarczych mię-

${ }^{1}$ http://www.sgh.waw.pl/imsg.

2 Por. A. Bąkiewicz, U. Żuławska (red.), Rozwój w dobie globalizacji, PWE, Warszawa 2010, s. 323-324; L. Ciamaga, Światowa gospodarka rynkowa, PWN, Warszawa 1990, s. 234-235; L. Żurawicki, Korporacje wielonarodowe w handlu swiatowym, PWE, Warszawa 1983, s. 20-28.

${ }^{3}$ UNCTAD, World Investment Report 2001, s. 275; A. B. Kisiel-Łowczyc (red.), Wspótczesna gospodarka światowa, Wyd. Uniwersytetu Gdańskiego, Gdańsk 2003, s. 13-14. 
dzy filiami (oddziałami), w efekcie czego działalność każdej z nich może wywierać istotny wpływ na funkcjonowanie pozostałych ${ }^{4}$.

Korporacje transnarodowe prowadzą działalność o zasięgu globalnym. Współcześnie najczęściej są to firmy, których obroty towarowe i kapitałowe skoncentrowane są w trzech najbardziej rozwiniętych regionach świata: Ameryce Północnej (głównie USA), Europie (państwa Unii Europejskiej) oraz w Azji Południowo-Wschodniej (Japonia, Chiny, Indie). Stąd często używa się terminu tzw. triadycznej gospodarki światowej (ang. triadic word economy). Zasadniczo można przyjąć, że KTN mają tendencję do wchodzenia na rynki, które są bezpieczne z punktu widzenia stabilności społeczno-politycznej, spełniają określone kryteria opłacalności ekonomicznej (np. co do wielkości i chłonności rynku) oraz dopuszczają funkcjonowanie KTN w swoim lokalnym ustawodawstwie ${ }^{5}$. W krajach wysoko uprzemysłowionych KTN lokuja swoje zasoby głównie $\mathrm{w}$ sferze usług oraz - w mniejszym stopniu - w przemyśle przetwórczym. Z kolei w krajach słabo rozwiniętych przedmiotem zainteresowania KTN jest przemysł wydobywczy, spożywczy, metalowy, tytoniowy i chemiczny ${ }^{6}$.

Do najważniejszych funkcji jakie pełnią korporacje transnarodowe w gospodarce światowej zaliczyć należy: pobudzanie wzrostu i efektywności gospodarczej, zwiększanie konkurencyjności gospodarki, stymulowanie restrukturyzacji przez przejęcia i fuzje, aktywizowanie lokalnych zasobów i konkurencji na rynku, transmitowanie nowych metod i wzorców, wiedzy i technologii, generowanie miejsc pracy, wyrównywanie poziomu rozwoju krajów lub/i regionów, integrowanie działalności przedsiębiorstw i gospodarki oraz wpływanie na procesy, jakie zachodzą w gospodarce światowej ${ }^{7}$. Priorytetowym celem działalności KTN jest uzyskanie efektywności ekonomicznej gwarantującej maksymalizację zysków tak w krótkim, jak i długim horyzoncie czasu oraz poszukiwanie nowych wymiarów ekspansji oraz innowacji. Korporacje transnarodowe jako firmy o globalnej skali działania mogą sprzedawać swoje produkty na całym świecie dzięki międzynarodowej sieci sprzedaży oraz czynnikom produkcji umożliwiającym uzyskanie przewagi konkurencyjnej w wyniku wykorzystania efektów skali. Specjalizacja działalności w ramach filii zlokalizowanych na wszystkich kontynentach, elastyczność organizacyjna, możliwość dokonywania transakcji w ramach własnych struktur organizacyjnych oraz su-

${ }^{4}$ http://www.sgh.waw.pl/imsg.

5 A. Bąkiewicz, U. Żuławska (red.), op. cit., s. 324.

${ }^{6}$ UNCTAD, World Investment Report 2006, s. 280.

${ }^{7}$ J. Rymarczyk (red.), Międzynarodowe stosunki gospodarcze, PWE, Warszawa 2010, s. 418 oraz http://pl.wikipedia.org/wiki/Korporacja_mi\%C4\%99dzynarodowa. 
werenność tych podmiotów umożliwiają im osiągnięcie wysokiej efektywności działania na poziomie globalnym dzięki obniżeniu kosztów netto w całym systemie korporacyjnym (choć nie zawsze we wszystkich jednostkach organizacyjnych w danym czasie) niezależnie od interesów poszczególnych państw. Umiejętne wykorzystanie przez KTN istniejących w świecie zróżnicowanych uwarunkowań ekonomicznych, geograficzno-naturalnych, instytucjonalno-politycznych oraz społeczno-kulturowych sprawia, że są one w stanie osiągnąć znaczny poziom globalnej efektywności dzięki obniżce kosztów produkcji i oszczędności nakładów, wzrostowi wartości dodanej i uzyskiwanych przychodów, wykorzystaniu innowacji, nowych metod organizacji i zarządzania, lepszej koordynacji, szybszego przepływu informacji wewnątrz korporacji, wykorzystania internetu i handlu elektronicznego ${ }^{8}$.

Do podstawowego kanonu strategii kształtujących zagraniczną i międzynarodową politykę ekonomiczną realizowanych przez KTN należą: strategia narodowa oparta na rozwoju współpracy produkcyjnej, technicznej i handlowej z lokalnymi przedsiębiorstwami, strategia międzynarodowa, gdzie proces produkcyjny podzielony jest pomiędzy filie wyposażone w kapitał, technologię i know-how, które wykorzystują lokalne czynniki produkcji, strategia transnarodowa (filie zlokalizowane są w kilku regionach a działalność KTN opiera się na dążeniu do zdyskontowania czynników produkcji oraz warunków produkcji i zbytu w regionach) oraz strategia globalna, zorientowana na lokowanie filii w różnych regionach świata, mając na uwadze wzrost produkcji w ujęciu absolutnym, nie zaś komparatywnym ${ }^{9}$. KTN prowadzą działalność opierając się na własnym majątku produkcyjnym, jak i w niezależnych przedsiębiorstwach po zawarciu z nimi stosownych porozumień. Mają dostęp do taniej siły roboczej, często lokują swoje oddziały w krajach oferujących niskie podatki lub możliwość uzyskania innej przewagi konkurencyjnej. Jako podmioty o ogromnym potencjale finansowym mają często uprzywilejowaną pozycję względem firm funkcjonujących w danym kraju. W systemie rozbudowanych powiązań sieciowych w ramach korporacji dokonuje się przepływ towarów, usług, informacji oraz czynników wytwórczych. Do podstawowych form zagranicznej ekspansji KTN należy w szczególności podejmowanie działalności inwestycyjnej w postaci bezpośrednich inwestycji zagranicznych (wspólne firmy, tworzenie własnych filii zagranicznych, zakładanie sieci międzyorganizacyjnych), eksport produktów lub/i usług, sprzedaż licencji zagranicznym odbiorcom oraz alianse strategiczne $z$ innymi przedsiębiorstwami. Obecnie obserwuje się wzrost licz-

${ }^{8}$ http://www.sgh.waw.pl/imsg.

9 Zob.: P. Bożyk, Międzynarodowe stosunku ekonomiczne. Teoria i polityka, PWE, Warszawa 2008, s. 300. 
by transgranicznych fuzji i przejęć, aliansów strategicznych, zwiększanie różnorodności powstałych organizmów ekonomicznych, zwiększanie zasięgu sieci powiązań międzykorporacyjnych, nawiązywanie współpracy z firmami lokalnymi oraz wirtualizację dużej części działalności, w efekcie czego powstają coraz większe i bardziej skomplikowane organizmy gospodarcze, w odniesieniu do których coraz trudniej zdefiniować można właścicieli czy przypisać im określoną przynależność państwową ${ }^{10}$. Procesowi relatywnie szybkiego rozwoju KTN sprzyja fakt, iż większość współczesnych przedsiębiorstw zorganizowana jest w formie spółek akcyjnych, co znacznie ułatwia dokonywanie przekształceń strukturalnych oraz własnościowych np. w drodze inwestycji kapitałowych $^{11}$. Najważniejsze motywy ekspansji zagranicznej przedsiębiorstw, w tym KTN sklasyfikować można w czterech grupach:

- rynkowe (m.in. wejście na nowe rynki i/lub wzrost udziału w rynkach, dynamiczny rozwój rynków zagranicznych, kurczenie się popytu na rynku krajowym, istnienie wolnych mocy produkcyjnych, chęć wyprzedzenia konkurencji),

- kosztowe (głównie obniżenie kosztów produkcji i wzrost stopy zysku, wykorzystanie korzyści skali, wzrost rentowności przedsiębiorstwa, niższe koszty pracy zagranicą, niższe koszty czynników produkcji i podatki zagranicą, mniejsze wymagania dotyczące ochrony środowiska zagranicą, istnienie specjalnych stref ekonomicznych czy parków technologicznych zagranica),

- zaopatrzeniowe (brak lub wyczerpywanie się własnych surowców naturalnych, niskie koszty transportu, dostęp do nowoczesnej wiedzy, zaawansowanych technologii),

- prawne i polityczne (wsparcie inwestycji bezpośrednich zagranicą, możliwość skorzystania $z$ narzędzi wspierania eksportu zagranicą, chęć uniezależnienia krajów od strategicznych dostawców poprzez strategię dywersyfikacji, istnienie restrykcyjnych regulacji prawnych w kraju macierzystym czy ekonomiczne wsparcie ważnych politycznie krajów) $)^{12}$.

\section{ZNACZENIE KTN}

O zwiększającej się roli oraz znaczeniu korporacji transnarodowych we współczesnym świecie świadczy dynamicznie wzrastająca w ostatnich latach liczba

${ }^{10} \mathrm{http}: / /$ www.sgh.waw.pl/imsg.

11 A. B. Kisiel-Łowczyc (red.), op. cit., s. 14.

12 R. Orłowska, K. Żołądkiewicz K. (red.), Globalizacja i regionalizacja w gospodarce światowej, PWE, Warszawa 2012, s. 46. 
tych podmiotów, ich geograficzny i przedmiotowy zasięg działania, potencjał finansowy, wysoki poziom innowacyjności oraz dominujący udział w wykorzystaniu kapitału intelektualnego i zdobyczy rewolucji informacyjnej ${ }^{13}$. Wartość przychodów największych korporacji przewyższa PKB wielu państw, są także podmiotami, które cechuje najwyższy w skali światowej poziom prywatnych nakładów na badania i rozwój oraz udział w handlu technologiami. Ogromny potencjał ekonomiczny KTN, skala oraz względna swoboda prowadzenia działalności na ponadnarodową skalę sprawiają, że są to podmioty mogące w istotny sposób wpływać na politykę wewnętrzną i zagraniczną oraz stosunki międzynarodowe poszczególnych państw, także w wymiarze pozaekonomicznym. Są one aktywnymi podmiotami środowiska międzynarodowego, wpływającymi na kształt i przebieg procesów w nim zachodzących kierując się przy tym wymogami efektywności własnych przedsięwzięć i chęcią generowania możliwie największych zysków. Do wzrostu znaczenia KTN jako podmiotów w istotny sposób wpływających na kształt stosunków międzynarodowych, szczególnie silnie w latach 90 . XX wieku przyczyniły się postępujące procesy globalizacyjne, klimat polityczny sprzyjający znoszeniu ograniczeń w międzynarodowej działalności gospodarczej, narastająca integracja gospodarcza państw, regulacje promujące swobodny przepływ kapitału finansowego, ludzkiego i rzeczowego, postępujący proces liberalizacji rynku oraz rozwój cyberprzestrzeni ${ }^{14}$.

Próba zdefiniowania znaczenia KTN w gospodarce światowej wymaga przyjęcia określonych kryteriów oceny. Do najczęściej wykorzystywanych mierników, mających największe znaczenie dla określenia ekonomicznej pozycji KTN, należą: wartość przychodów ze sprzedaży, umożliwiająca wskazanie korporacji o największej sile handlowej, wartość rynkowa poszczególnych firm, określająca ich pozycję kapitałową, wartość najcenniejszych marek na świecie oraz wartość zagranicznych aktywów będących w posiadaniu KTN, dzięki czemu możliwe jest wskazanie firm-inwestorów najbardziej zaangażowanych poza krajem macierzystym ${ }^{15}$. Obraz ekonomicznej siły KTN daje także porównanie przychodów ze sprzedaży KTN oraz PKB największych gospodarek świata.

W ostatnich dekadach obserwuje się systematyczny wzrost globalnego znaczenia KTN. Prawidłowość ta jest wynikiem zwiększającego się po-

$13 \mathrm{http} / / /$ stosunki-miedzynarodowe.pl/index.php?option=com_content\&view=article\&id=555: korporacje-transnarodowe\&catid=57:k\&Itemid=92.

${ }^{14}$ Ibidem.

15 A. Zorska, Korporacje transnarodowe. Przemiany, oddziatywania, wyzwania, PWE, Warszawa 2007 , s. 92. 
ziomu umiędzynarodowienia ich aktywności oraz wartości znajdujących się w ich dyspozycji aktywów. Należy odnotować przy tym zwiększenie liczby KTN pochodzących z krajów o największej dynamice rozwoju oraz wzrost liczby korporacji w sektorach usług, zwłaszcza telekomunikacyjnych, finansowych i komunalnych. Ponadto widoczny jest również wzrost aktywności KTN rodzinnych (family-owned) i państwowych (tj. bazujących na państwowych aktywach) z rynków wschodzących ${ }^{16}$. W 2008 roku 300 największych KTN posiadało $25 \%$ światowych zasobów produkcyjnych, uczestniczyły one w $70 \%$ światowego handlu, wartość ich skumulowanych BIZ oceniano na 1,83 bln USD, zaś wartość sprzedaży na 31 bln USD. Ponad 78 tys. macierzystych KTN posiadało blisko 927 tys. filii zagranicznych, w których zatrudniano łącznie $82 \mathrm{mln}$ osób ${ }^{17}$. W 2012 roku firmy znajdujące się na liście Global 2000 (ranking największych firm na świecie opracowywany przez magazyn „Forbes”) zrealizowały obroty na kwotę 36 bilionów dolarów (wzrost w porównaniu do roku 2011 o 12\%) oraz zyski na poziomie 2,64 biliona USD (wzrost o 11\% w odniesieniu do roku 2011). Łączny poziom aktywów firm objętych rankingiem kształtował się na poziomie149 bln USD (wzrost o 8\%), zaś ich wartość rynkowa, której ocena pozwala odnieść się do ich wyników handlowych i finansowych oraz zdolności generowania dywidendy przez poszczególne podmioty, wyniosła 37 bln USD. Łącznie zatrudniały one $83 \mathrm{mln}$ pracowników. Zestawienie objęło firmy z 66 krajów. Największa reprezentacja podmiotów pochodzi z USA (524 firmy) oraz Japonii (258 firm). Na kolejnych miejscach uplasowały się Chiny, które umocniły swoją pozycję oraz Korea Południowa, Indie i Wielka Brytania. Do państw, które osiągnęły wysoki poziom wszystkich uwzględnianych w zestawieniu wskaźników należą: USA, Tajlandia, Filipiny, Arabia Saudyjska oraz Zjednoczone Emiraty Arabskie. Autorzy rankingu odeszli od wcześniejszej metodologii, według której poszczególne kryteria były traktowane oddzielnie. W 2012 roku do ustalenia potencjału największych firm świata przyjęto metodologię, zgodnie z którą cztery podstawowe kategorie tj. sprzedaż, zyski, aktywa oraz wartość rynkowa firm miały jednakową wagę przy określaniu pozycji firm (tab. 1). Biorąc pod uwagę pierwszą dziesiątkę zestawienia znalazło się w niej 5 firm amerykańskich, 2 z Chin oraz po jednej z Holandii, Wielkiej Brytanii i Brazylii. Dwie firmy osiągnęły przychody ze sprzedaży przekraczające 400 mld USD (koncerny paliwowe Exxon Mobile oraz Royal Dutch Shell). Firmy z pierwszej dziesiątki rankingu zgromadziły aktywa o łącznej wartości 10573,3 mld USD oraz zrealizowały łączny zysk netto na poziomie 213,4 mld USD.

\footnotetext{
${ }^{16}$ R. Orłowska, K. Żołądkiewicz (red.), op. cit., s. 56.

17 Ibidem, s. 54.
} 
Obserwowane na przestrzeni ostatnich dekad umocnienie międzynarodowej pozycji gospodarczej KTN oraz ich potencjału mierzonego przede wszystkim wielkością realizowanych obrotów i zysków sprawia, że często są one porównywane z państwami pod względem zasobów, geograficznej skali działania oraz powiązań z rządami państw, w których działają. Najczęściej obieranym kryterium porównawczym są posiadane zasoby finansowe określające międzynarodowy potencjał korporacji ${ }^{18}$.

Tabela 1. Potencjał ekonomiczny największych firm świata

\begin{tabular}{|c|l|l|c|c|c|c|}
\hline LP. & \multicolumn{1}{|c|}{ FIRMA } & KRA & $\begin{array}{c}\text { SPRZEDAŻ } \\
\text { (MLD USD) }\end{array}$ & $\begin{array}{c}\text { ZYSK NETTO } \\
\text { (MLD USD) }\end{array}$ & $\begin{array}{c}\text { AKTYWA } \\
\text { (MLD USD) }\end{array}$ & $\begin{array}{c}\text { WARTOŚć RYNKOWA } \\
\text { (MLD USD) }\end{array}$ \\
\hline 1 & Exxon Mobile & USA & 433,5 & 41,1 & 331,1 & 407,4 \\
\hline 2 & JP Morgan Chase & USA & 110,8 & 19,0 & 2265,8 & 170,1 \\
\hline 3 & General Electric & USA & 147,3 & 14,2 & 717,2 & 213,7 \\
\hline 4 & Royal Dutch Shell & Holandia & 470,2 & 30,9 & 340,5 & 227,6 \\
\hline 5 & ICBC & Chiny & 82,6 & 25,1 & 2039,1 & 237,4 \\
\hline 6 & HSBC Holdings & Wielka Brytania & 102,0 & 16,2 & 2550 & 164,3 \\
\hline 7 & PetroChina & Chiny & 310,1 & 20,6 & 304,7 & 294,7 \\
\hline 8 & Berkshire Hathaway & USA & 143,7 & 10,3 & 392,6 & 202,2 \\
\hline 9 & Wells Fargo & USA & 87,6 & 15,9 & 1313,9 & 178,7 \\
\hline 10 & Petrobras-Petroleo Brasil & Brazylia & 145,9 & 20,1 & 319,4 & 180,0 \\
\hline 11 & BP & Wielka Brytania & 375,5 & 25,7 & 292,5 & 147,4 \\
\hline 12 & Chevron & USA & 236,3 & 26,9 & 209,5 & 218,0 \\
\hline 13 & China Construction Bank & Chiny & 68,7 & 20,5 & 1637,8 & 201,9 \\
\hline 14 & Citigroup & USA & 102,6 & 11,1 & 1873,9 & 107,5 \\
\hline 15 & Gazprom & Rosja & 117,6 & 31,7 & 302,6 & 159,8 \\
\hline 16 & Wal-Mart Stores & USA & 447,0 & 15,7 & 193,4 & 208,4 \\
\hline 17 & Volkswagen Group & Niemcy & 221,9 & 21,5 & 328,7 & 79,5 \\
\hline 18 & Total & Francja & 216,2 & 15,9 & 213,0 & 132,4 \\
\hline 19 & Agricultural Bank of China & Chiny & 62,4 & 14,4 & 1536,9 & 154,8 \\
\hline 20 & BNP Paribas & Francja & 119,0 & 7,9 & 2539,1 & 61,5 \\
\hline
\end{tabular}

1 według kapitalizacji rynkowej.

Źródło: Global 2000, Forbes, http://www.forbes.com/global2000/.

Tabela 2 zawiera dane obrazujące dynamikę zmian przychodów ze sprzedaży oraz zysków osiąganych przez korporacje z pierwszej dziesiątki rankingu największych firm na świecie na przestrzeni lat 2005 i 2012 (nie podano nazw firm, gdyż ich lista w tym okresie ulegała modyfikacjom). Jak wynika $z$ tabe-

18 A. Jarczewska-Romaniuk, Przedsiębiorstwa międzynarodowe, Oficyna Wydawnicza Branta, Bydgoszcz-Warszawa 2004, s. 97. 
li tempo wzrostu tych parametrów jest bardzo znaczące, co potwierdza tezę o rosnącym znaczeniu potencjału KTN w gospodarce światowej.

Tabela 2. Dynamika zmian przychodów i zysków KTN na przestrzeni lat 2005 i 2012 (w \%)

\begin{tabular}{|c|c|c|}
\hline LP. & $\begin{array}{c}\text { ZMIANA WIELKOŚCI PRZYCHODÓW } \\
\text { WG POZYCI W RANKINGU 2012/2005 }\end{array}$ & $\begin{array}{c}\text { ZMIANA POZIOMU ZYSKÓW } \\
\text { WG POZYCII W RANKINGU 2012/2005 }\end{array}$ \\
\hline 1 & $+68,23$ & $+62,26$ \\
\hline 2 & $+58,89$ & $+77,99$ \\
\hline 3 & $+65,07$ & $+85,92$ \\
\hline 4 & $+43,83$ & $+86,26$ \\
\hline 5 & $+93,89$ & $+71,00$ \\
\hline 6 & $+99,41$ & $+81,75$ \\
\hline 7 & $+50,13$ & $+125,51$ \\
\hline 8 & $+42,61$ & $+116,31$ \\
\hline 9 & $+55,22$ & $+146,85$ \\
\hline 10 & $+54,23$ & $+165,43$ \\
\hline
\end{tabular}

Źródło: obliczenia własne na podstawie Rankingu Forbes Global 2000 dla lat 2005 i 2012.

Porównanie wielkości przychodów osiąganych przez KTN oraz PKB największych gospodarek świata (tab. 1 i 3), choć często stosowane, może zostać uznane za mało obiektywne ze względu na dobór nieprzystających do siebie kryteriów (spółki klasyfikowane są według wartości sprzedaży, podczas gdy gospodarki narodowe według PKB, który mierzy wartość dodaną bardziej odpowiadającą kategorii zysku spółki $\left.{ }^{19}\right)$. Lepszym miernikiem siły danej KTN w gospodarce państwa goszczącego wydaje się wartość zysku po opodatkowaniu oraz wartości związane z działalnością zagraniczną (non-domestic activities $)^{20}$. Analiza wskazanych parametrów uprawnia do stwierdzenia, że wiele korporacji osiąga przychody na poziomie znacznie przekraczającym PKB określonych państw, co oddaje ich potencjał w zakresie miejsca we współczesnych relacjach międzynarodowych. Konkurencyjna wysoka pozycja KTN na tle PKB państw świadczy o szybkim wzroście ich obrotów, co zazwyczaj uwarunkowane jest sprzyjającą koniunkturą gospodarczą i ma związek z dynamicznym rozwojem tych podmiotów.

W dobie rozwoju gospodarki sieciowej, obok tak istotnych cech produktu, jak jego wartość użytkowa, funkcjonalność czy innowacyjność ważną rolę odgrywa sposób dotarcia do konsumentów na całym świecie. Stąd obok tradycyj-

19 Spótka coraz bardziej wspólna, „Forum” 2002, nr 11, s. 23, przedruk za: The Economist, „The Economist Newspaper" Ltd., 22.01.2002.

20 A. Rubner, The might of the multinationals: the rise and fall of the corporate legend, Praeger, New York 1990, s. 34. 
nych form promocji, zasadnicze znaczenie mają nowe kierunki kreowania globalnych marek przy wykorzystaniu takich kanałów dystrybucji jak internet czy produkt placement. Dla firm o uznanych markach (np. Nike) kreowanie dobrego wizerunku firmy staje się przepustką do większych obrotów i zysków realizowanych $\mathrm{z}$ tytułu handlu prawami do znaku firmowego ${ }^{21}$. Przedsiębiorstwa zajmujące czołowe pozycje w rankingu najcenniejszych marek (tab. 4), zorientowane są najczęściej na promowanie zunifikowanej silnej marki czy produktu oraz jednolitego hasła reklamowego w skali globalnej. Według wyliczeń firmy Interbrandt w 2010 roku w pierwszej dziesiątce najcenniejszych marek świata znalazło się aż 9 marek amerykańskich, zaś najcenniejszą z nich była Coca Cola (70,5 mld USD). Potwierdza to więc często powtarzaną tezę o amerykanizacji wzorców konsumpcyjnych w skali świata w dobie globalizacji. Ponad połowa ze 100 firm objętych rankingiem pochodzi z USA. W porównaniu z 2009 roku największy skok (o 9 miejsc) odnotowała firma Apple, której wartość wzrosła w odniesieniu do 2009 roku aż o 58\%, z kolei największy spadek w rankingu (z 8 na 14 pozycję) był udziałem fińskiej Nokii. Zdecydowanie mniejszą niż USA rolę odgrywają w rankingu firmy z Azji i Europy. Najwyższe miejsca (11 i 12) zajęli przedstawiciele branży motoryzacyjnej - japońska Toyota oraz niemiecki Mercedes-Benz. W zestawieniu dominują firmy z sektorów elektronicznego, usług finansowych, produkcji samochodów oraz FMCG, które zajęły 51 miejsc w setce najlepszych marek świata.

Tabela 3. Największe gospodarki świata w 2011 r.

\begin{tabular}{|c|l|l|l|l|l|}
\hline LP. & \multicolumn{1}{|c|}{ KRAJ } & $\begin{array}{c}\text { PKB (NOMINALNY) } \\
\text { W MLD USD }\end{array}$ & LP. & \multicolumn{1}{|c|}{ KRAJ } & \multicolumn{1}{|c|}{$\begin{array}{c}\text { PKB (NOMINALNY) } \\
\text { W MLD USD }\end{array}$} \\
\hline- & Unia Europejska & 17,611 & 11 & Kanada & 1,739 \\
\hline 1 & Stany Zjednoczone & 15,076 & 12 & Australia & 1,487 \\
\hline 2 & Chiny & 7,298 & 13 & Hiszpania & 1,480 \\
\hline 3 & Japonia & 5,867 & 14 & Meksyk & 1,154 \\
\hline 4 & Niemcy & 3,607 & 15 & Korea Południowa & 1,116 \\
\hline 5 & Francja & 2,778 & 16 & Indonezja & 846 \\
\hline 6 & Brazylia & 2,493 & 17 & Holandia & 838 \\
\hline 7 & Wielka Brytania & 2,431 & 18 & Turcja & 774 \\
\hline 8 & Włochy & 2,199 & 19 & Szwajcaria & 661 \\
\hline 9 & Rosja & 1,850 & 20 & Arabia Saudyjska & 597 \\
\hline 10 & Indie & 1,827 & - & Reszta świata & 13,781 \\
\hline
\end{tabular}

Źródło: World Economic Outlook Database, MFW, October 2012.

${ }^{21}$ S. Sala, Rozwój korporacji transnarodowych w gospodarce światowej, Przedsiębiorczość - Edukacja nr 1, Kraków 2005, s. 38. 
Tabela 4. Firmy mające najcenniejsze marki i wartość tych marek

\begin{tabular}{|c|c|c|c|c|c|}
\hline LP. & FIRMA & $\begin{array}{l}\text { WARTOŚĆ MARKI } \\
\text { W MLD USD }\end{array}$ & LP. & FIRMA & $\begin{array}{l}\text { WARTOŚĆ MARKI } \\
\text { W MLD USD }\end{array}$ \\
\hline 1 & Coca-Cola (USA) & 70,5 & 16 & Louis Vuitton (Francja) & 21,9 \\
\hline 2 & IBM (USA) & 64,7 & 17 & Apple (USA) & 21,1 \\
\hline 3 & Microsoft (USA) & 60,9 & 18 & Marlboro (USA) & 20,0 \\
\hline 4 & Google (USA) & 43,6 & 19 & Samsung (Korea Płd.) & 19,5 \\
\hline 5 & GE (USA) & 42,8 & 20 & Honda (Japonia) & 18,5 \\
\hline 6 & McDonald's (USA) & 33,6 & 21 & H\&M (Szwecja) & 16,1 \\
\hline 7 & Intel (USA) & 32,0 & 22 & Oracle (USA) & 14,9 \\
\hline 8 & Nokia (Finlandia) & 29,5 & 23 & Pepsi (USA) & 14,1 \\
\hline 9 & Disney (USA) & 28,7 & 24 & American Express (USA) & 13,9 \\
\hline 10 & HP (USA) & 26,9 & 25 & Nike (USA) & 13,7 \\
\hline 11 & Toyota (Japonia) & 26,2 & 26 & SAP (Niemcy) & 12,8 \\
\hline 12 & Mercedes-Benz (Niemcy) & 25,2 & 27 & Nescafe & 12,8 \\
\hline 13 & Gilette (USA) & 23,3 & 28 & Ikea (Szwecja) & 12,5 \\
\hline 14 & Cisco (USA) & 23,2 & 29 & J.P.Morgan (USA) & 12,3 \\
\hline 15 & BMW (Niemcy) & 22,3 & 30 & Budweiser & 12,3 \\
\hline
\end{tabular}

Źródło: Interbrand http://www.biznes.banzaj.pl/Ranking-najcenniejszych-marek-swiata.

Informacji na temat skali ponadnarodowej działalności KTN dostarczają dane odnoszące się do wielkości zagranicznych aktywów KTN, sprzedaży i zatrudnienia zagranicą, jak również wskaźnik transnacjonalizacji KTN (tab. 5). Indeks transnacjonalizacji (transnationality indeks, TNI) stanowi średnią wielkość z następujących relacji: aktywów zagranicznych do całkowitych, sprzedaży zagranicznej do ogólnej oraz zatrudnienia zagranicą do całkowitego. Korporacje należące do grupy 100 największych posiadaczy zagranicznych aktywów odgrywają główną rolę w grupie pond 78 tys. KTN. Cechuje je wysoki wskaźnik udziału w wartości zagranicznej sprzedaży oraz aktywów, co oznacza, że wykorzystują one wymianę handlową jako formę ekspansji w skali globalnej. Gałęziowa struktura KTN jest mocno zróżnicowana. Choć podmioty te są obecne niemal we wszystkich przemysłach i sektorach gospodarki, można stwierdzić, że relatywnie najczęściej zainteresowane są one podejmowaniem działalności w gałęziach wysokich technologii, nauko- i kapitałochłonnych. Prawidłowością jest także wzrost zainteresowania sektorem szeroko pojmowanych usług i rosnąca liczbą KTN w informatyce (IT), bankowości i handlu detalicznym (wielkie sieci handlowe), jak również obserwowany w ostatnich latach zwrot ku przemysłowi wydobywczemu i przetwórczemu ropy naftowej i metali, co należy wiązać ze wzrostem znaczenia w gospodarce światowej sektora energetycznego i przetwórstwa metali. Dokonywane przez KTN 
zakupy aktywów w sektorach telekomunikacji, dostaw wody i elektryczności, często były następstwem procesów prywatyzacji firm państwowych, jakie miały miejsce w wielu krajach ${ }^{22}$.

Cechą globalnej gospodarki jest wykreowanie nowego rodzaju relacji i wzajemnych powiązań pomiędzy jej podmiotami. W efekcie coraz częściej mamy do czynienia z przypadkami, gdy geoekonomia zyskuje prymat nad geopolityką implikując zawiązywanie nowego rodzaju interesów na ponadnarodową skalę. Korporacje transnarodowe są jedną z grup podmiotów pozapaństwowych, które szczególnie wyraźnie artykułują swoje interesy na rynkach krajowych i międzynarodowych. KTN stanowią często siłę napędową postępu ekonomicznego i technicznego oraz pełnią rolę dostawców wiedzy i zaawansowanych technologii, dzięki którym mogą one wywierać istotny wpływ na poziom rozwoju gospodarczego kraju goszczącego. Obok szeregu omówionych wcześniej korzyści wynikających $\mathrm{z}$ aktywności KTN na rynkach międzynarodowych, działalność tych podmiotów wywołuje również negatywne następstwa. Lista zarzutów formułowanych najczęściej pod adresem korporacji obejmuje głównie stosowanie w biznesie praktyk utrudniających rozwój firm krajowych (tworzenie barier wejścia do sektorów, struktur bliskich monopolom, stosowanie cen transferowych), możliwość nadmiernego uzależnienia gospodarek krajowych od obcego kapitału w następstwie przejmowania kontroli nad branżami strategicznymi oraz ryzyko wystąpienia tzw. efektu wypierania, którego bezpośrednią konsekwencją jest ograniczanie krajowej aktywności inwestycyjnej ${ }^{23}$. Ponadto KTN zarzuca się próby podporządkowywania instytucji państwa własnym interesom poprzez wywieranie nacisków za pomocą narzędzi finansowych i technologicznych (w zamian za dostęp do kapitału i nowoczesnych technologii KTN oczekują stworzenia im wyjątkowo korzystnych warunków do lokowania kapitału w postaci ulg i zwolnień z opłat celnych i podatkowych, co ma swoje negatywne konsekwencje w postaci zmniejszenia poziomu dochodów danego państwa) czy przekształcenia na lokalnych rynkach pracy (niekorzystne dla pracowników zmiany w kodeksie pracy: dążenie do ograniczania przywilejów socjalnych, obniżanie płac) ${ }^{24}$. Potencjał ekonomiczny korporacji, ich system zarządzania oraz rozbudowana sieć przedstawicielstw sprawiły, iż podmioty te uzyskały znaczny stopień kontroli i wpływu na wzrost gospodarczy i rozwój państw, przemysł, handel, konsumpcję oraz międzynarodowy podział pracy ${ }^{25}$.

22 World Investment Report 2011, UNCTAD.

${ }^{23}$ Wystąpienie efektu wypierania stwierdzono w odniesieniu do krajów Ameryki Łacińskiej i Karaibów. World Investment Report 1999, UNCTAD, s. 189-193.

${ }^{24}$ S. Sala, op. cit., s. 39; A. Jarczewska-Romaniuk, op. cit., s. 168.

25 http://www.sgh.waw.pl/imsg. 


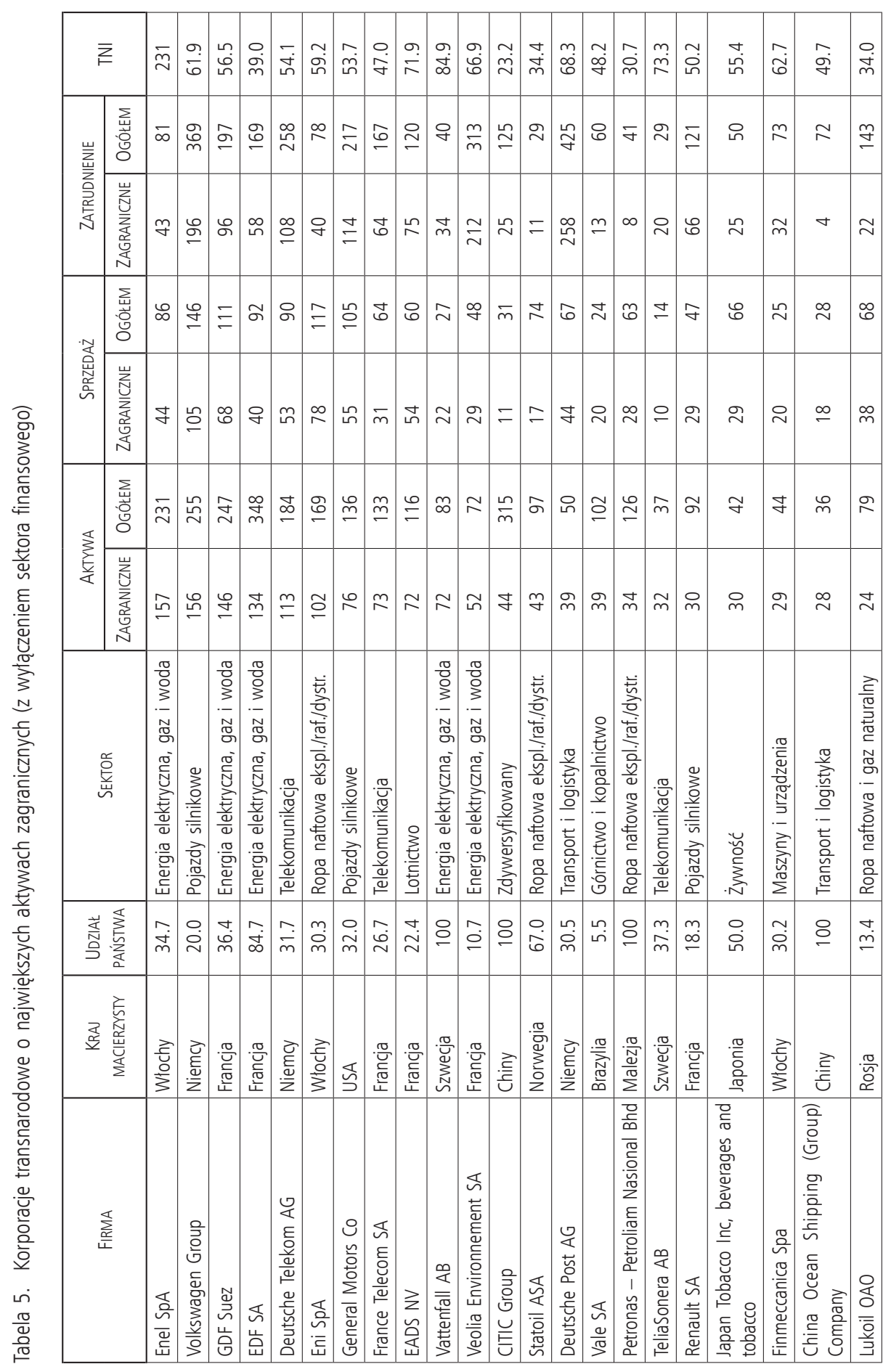




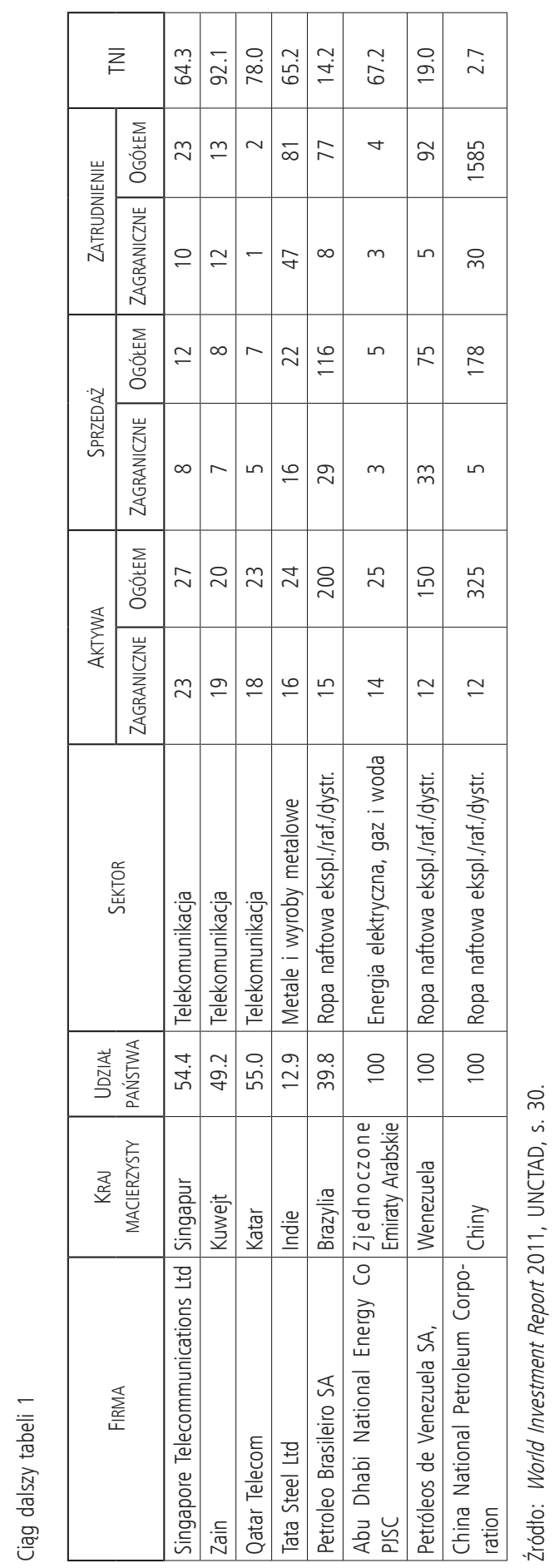


Dynamiczny przebieg procesów globalizacji sprzyja umacnianiu ekonomicznej pozycji przedsiębiorstw transnarodowych. W najbliższym czasie należy spodziewać się wzrostu znaczenia KTN jako następstwa tworzenia przez nie nowych relacji gospodarczych, społecznych i politycznych, których podłożem jest posiadany potencjał finansowy i rzeczowy, skutecznego wpływania na strukturę i jakość konkurencji międzynarodowej, aktywizowania lokalnych zasobów wytwórczych oraz wykorzystania liberalizacji do powiększania skali prowadzonej działalności, głównie w drodze poszukiwania obszarów/regionów o niskich kosztach czynników produkcji oraz względnie mało dotkliwych barierach ochronnych rynku wewnętrznego ${ }^{26}$.

\section{ZAKOŃCZENIE}

Znaczenia korporacji transnarodowych we współczesnej gospodarce nie sposób przecenić. Do najważniejszych funkcji, jakie KTN pełnią w gospodarce światowej zaliczyć można: transmitowanie nowych metod i wzorców, wiedzy i technologii, generowanie miejsc pracy, pobudzanie wzrostu i efektywności gospodarczej, aktywizowanie lokalnych zasobów i konkurencji na rynku czy podnoszenie poziomu rozwoju krajów goszczących. Według rankingu największych firm na świecie KTN zrealizowały w 2012 roku obroty na kwotę 36 bilionów USD oraz zyski na poziomie 2,64 biliona USD, posiadały aktywa o łącznej wartości 149 bln USD, a ich wartość rynkowa wyniosła 37 bln USD. Ogółem zatrudniały $83 \mathrm{mln}$ pracowników. Wartość realizowanych przez KTN przychodów ze sprzedaży często przewyższa poziom PKB niektórych państw.

Będąc aktywnym uczestnikiem międzynarodowych stosunków ekonomicznych korporacje transnarodowe dysponujące znacznym potencjałem kapitałowym, produkcyjnym i technologicznym wpływają w znacznym stopniu na kształtowanie relacji zachodzących w gospodarce światowej i w istotny sposób zmieniają warunki konkurencyjności. Dane liczbowe ilustrujące skalę działalności KTN świadczą o sukcesywnym zwiększaniu ich znaczenia dla funkcjonowania gospodarki globalnej oraz zagospodarowywaniu części przestrzeni ekonomicznej, która dotychczas była domeną gospodarek narodowych. Procesowi relatywnie szybkiego rozwoju KTN sprzyja fakt, iż większość współczesnych przedsiębiorstw zorganizowana jest w formie spółek akcyjnych, co znacznie ułatwia dokonywanie przekształceń strukturalnych oraz własnościowych np. w drodze inwestycji kapitałowych. Zasoby KTN stanowią dla poszczegól-

${ }^{26}$ J. Rymarczyk (red.), Międzynarodowe stosunki gospodarcze, PWE, Warszawa 2006, s. $413-414$. 
nych gospodarek narodowych atrakcyjny obiekt konkurowania, gdyż stanowią potencjalne źródło poprawy poziomu rozwoju społeczno-gospodarczego. Biorąc pod uwagę fakt, iż KTN są nośnikami zarówno pozytywnych jak i negatywnych efektów swojej działalności, rolą rządów jest wyważenie wzajemnych korzyści i kosztów związanych z obecnością KTN w danym kraju. Z jednej strony kapitał przedsiębiorstw międzynarodowych może stać się dla państw słabiej rozwiniętych trampoliną do przyspieszenia rozwoju społeczno-gospodarczego, z drugiej należy pamiętać, że nadmierny wpływ korporacji na decyzje podejmowane przez rządy państw goszczących czy krajów macierzystych może przyczynić się do niewspółmiernego drenażu ich gospodarki.

\section{BIBLIOGRAFIA}

Bąkiewicz A., Żuławska U. (red.), Rozwój w dobie globalizacji, PWE, Warszawa 2010. Bożyk P., Międzynarodowe stosunku ekonomiczne. Teoria i polityka, PWE, Warszawa 2008.

Ciamaga L., Światowa gospodarka rynkowa, PWN, Warszawa 1990.

Forum nr 11/2002, Spótka coraz bardziej wspólna, przedruk za The Economist, „The Economist Newspaper" Ltd., 22.01.2002.

Global 2000, Forbes, http://www.forbes.com/global2000/.

http://pl.wikipedia.org/wiki/Korporacja_mi\%C4\%99dzynarodowa.

http://stosunki-miedzynarodowe.pl/index.php?option=com_content\&view=article\&id $=555:$ korporacje-transnarodowe $\&$ catid $=57: \mathrm{k} \& I$ temid $=92$.

http://www.sgh.waw.pl/imsg.

Interbrand http://www.biznes.banzaj.p1/Ranking-najcenniejszych-marek-swiata.

Jarczewska-Romaniuk A., Przedsiębiorstwa międzynarodowe, Oficyna Wydawnicza Branta, Bydgoszcz 2003.

Kisiel-Łowczyc A. B. (red.), Wspótczesna gospodarka światowa, Wyd. Uniwersytetu Gdańskiego, Gdańsk 2003.

Orłowska R., Żołądkiewicz K. (red.), Globalizacja i regionalizacja w gospodarce światowej, PWE, Warszawa 2012.

Rubner A., The might of the multinationals: the rise and fall of the corporate legend, Praeger, New York, 1990.

Rymarczyk J. (red.), Międzynarodowe stosunki gospodarcze, PWE, Warszawa 2010.

Rymarczyk J. (red.), Międzynarodowe stosunki gospodarcze, PWE, Warszawa 2006.

Sala S., Rozwój korporacji transnarodowych w gospodarce światowej, Przedsiębiorczość - Edukacja nr 1, Kraków 2005.

World Economic Outlook Database, MFW, October 2012.

World Investment Report 2001, 2006, 2011, UNCTAD.

Zorska A., Korporacje transnarodowe. Przemiany, oddziatywania, wyzwania, PWE, Warszawa 2007.

Żurawicki L., Korporacje wielonarodowe w handlu światowym, PWE, Warszawa 1983. 


\title{
ZNACZENIE KORPORACJI TRANSNARODOWYCH W GOSPODARCE ŚWIATOWEJ
}

\author{
STRESZCZENIE
}

Współcześnie uważa się, że korporacje transnarodowe, obok państw, instytucji i organizacji międzynarodowych, stały się głównym i niezwykle aktywnym podmiotem procesów globalizacji o istotnej sile wpływu na zmiany zachodzące w gospodarce światowej. Funkcjonowanie firm o zasięgu globalnym budzi jednak wiele kontrowersji. $Z$ jednej strony przysparzają krajowi goszczącemu szereg określonych korzyści (nowe inwestycje, miejsca pracy), $z$ drugiej negatywnie ocenia się ich próby działania ponad ustawodawstwem krajowym czy transfer zysków zagranicę. Celem artykułu jest próba oceny znaczenia ekonomicznego tych podmiotów we współczesnej gospodarce.

\section{THE IMPORTANCE OF TRANSNATIONAL CORPORATIONS IN THE WORLD}

\section{SUMMARY}

Nowadays, it is believed that transnational corporations, in addition to states, international institutions and organizations, have become a major and extremely active subject of globalization with very important influence on changes in the global economy. The functioning of global companies, however, raises a lot of controversy. On one hand, it can bring a number of specific benefits (new investments, jobs) to the host countries, on the other hand, they face a lot of critics to their operation, attempts to influence national legislation and transfer of profits abroad. The article attempts to assess the economic significance of these entities in the modern economy. 
